\title{
In Vitro Effect of Photodynamic Therapy on Aggregatibacter actinomycetemcomitans and Streptococcus sanguinis
}

\author{
Fabiano Dalla Lana MATTIELLO \\ Alan Augusto Kalife COELHO \\ Odair Pimentel MARTINS \\ Rodrigo Dalla Lana MATTIELLO \\ José Peixoto FERRÃO JÚNIOR \\ Department of Prosthetic and Restorative Dentistry, Dental School "Prof. Albino Coimbra Filho", \\ UFMS - Federal University of Mato Grosso do Sul, Campo Grande, MS, Brazil
}

\begin{abstract}
New periodontal disease treatments are needed to prevent infection progression. Photodynamic therapy (PDT) is one of the greatest pledges for this purpose. It involves the use of light of specific wavelength to activate a nontoxic photosensitizing agent in the presence of oxygen for eradication of target cells, and can be used for photokilling of microorganisms. This study evaluated in vitro the photodynamic effect of $0.01 \%$ toluidine blue-O (TBO) in combination with an AlGaInP diode laser light source on Aggregatibacter actinomycetemcomitans (A.a.) and Streptococcus sanguinis (S.s.). Suspensions (2 mL) containing A.a. and S.s. at $1.5 \mathrm{x} 10^{8} \mathrm{CFU} /$ $\mathrm{mL}$ concentration were prepared and divided into 3 groups: Control group (no treatment), Dye group (inoculum and TBO for 5 min) and Dye/Laser group (inoculum, TBO for $5 \mathrm{~min}$ and laser for $3 \mathrm{~min}$ ). Next, a dilution for subsequent subculture in $20 \mathrm{~mL}$ of Trypic Soy Agar (A.a) and Brucella Agar (S.s.) in Petri dishes (Pourplate Method) was done. Incubation of A.a. in microaerophilia and S.s. in aerobiosis at $35^{\circ} \mathrm{C}$ for $48 \mathrm{~h}$ was performed for subsequent visual counting of CFU/mL. Data were analyzed by one-way ANOVA and Tukey's HSD test at $5 \%$ significance level. For both strains, the control group showed a significantly higher $(\mathrm{p}<0.05)$ bacterial growth $\left(1.5 \times 10^{8} \mathrm{CFU} / \mathrm{mL}\right)$, while the Dye group presented no significant reduction $(\mathrm{p}>0.05)$ in the CFU counts. The Dye/Laser group presented a significant decrease in the CFU counts $(\mathrm{p}<0.05)$ compared with the Control group $(61.53 \%$ for A.a. and $84.32 \%$ for S.s. $)$. It may be concluded that PDT was effective in reducing the numbers of A.a. and S.s. in vitro.
\end{abstract}

Key Words: periodontitis, photodynamic therapy, tolonium chloride.

\section{INTRODUCTION}

Streptococcus sanguinis (S.s.), formerly known as $S$. sanguis, is a Gram-positive coccoid, facultative anaerobe bacteria (1). It is one of the microorganisms responsible for pioneering colonizing development, due to the recognition of specific receptors of the acquired pellicle on enamel surface (2).

Aggregatibacter actinomycetemcomitans (A.a.), formerly known as Actinobacillus actinomycetemcomitans, is a microaerophilic, facultative anaerobic, Gram-negative coccoid rod (3). A.a. elimination is highly important due to its association with the etiology and pathogenesis of periodontal disease (4), as it appears at critical levels in subgingival biofilms, which induces tissue destruction (5).

The goal of periodontal treatment is to restore biological compatibility of periodontally diseased root surfaces. Once mechanical scaling and root planning usually do not achieve complete removal of bacterial deposits, systemic and local antibiotics are occasionally administered, and its frequent use has a potential risk of producing antibiotic-resistant microorganisms (6).

Photodynamic therapy (PDT) is an effective and innovative microbicidal method (7), which involves the combination of a non-toxic dye (photosensitizer)

Correspondence: Dr. Fabiano Dalla Lana Mattiello, Departamento de Prótese e Odontologia Restauradora, Faculdade de Odontologia "Prof. Albino Coimbra Filho", UFMS, Avenida Senador Filinto Müller, S/N, Caixa Postal 549, 79080-190 Campo Grande, MS, Brasil. Tel: +55-67-3345-7681. e-mail: fabianodlm@hotmail.com 
and a visible light source. It shows a great microbicidal effect in addition to better access to sites that are inaccessible to conventional therapy (8). The use of PDT as an antimicrobial control method has local and specific effects, and also selectiveness for the pathogens (8). The aim of this study was to evaluate the microbicidal effect of this innovate periodontal therapy against oral pathogenic bacteria associated with plaque maturation and periodontal destruction.

\section{MATERIAL AND METHODS}

S.s. and A.a. strains were provided by the Microbiology Laboratory of the Department of Pathology of the Federal University of Mato Grosso do Sul, Brazil.

S.s. was incubated in Petri dishes with Brucella agar in aerobiosis while A.a. was incubated in Trypic Soy Agar (TSA) supplemented with $0.5 \%$ yeast extract in microaerophilic atmosphere at $35^{\circ} \mathrm{C}$ for $48 \mathrm{~h}$ to obtain strains at exponential growth phase. Next, S.s. and A.a. colony forming units (CFU) were inoculated into Brucella broth and Trypic Soy Broth (TSB) supplemented with $0.5 \%$ yeast extract, respectively. Then, $1 \mathrm{~mL}$ of CFU of each strain was aspirated with a disposable pipette from the dishes and the volume was dispersed in a sterile $10 \mathrm{~mL}$ tube, which was agitated in a tube agitator to spread bacterial strains. This tube was subjected to concentration analysis in a $640 \mathrm{~nm}$ spectrophotometer to reach a value between $0.08-0.1$ $\mathrm{nm}$ corresponding to the final concentration of $1.5 \mathrm{x}$ $10^{8} \mathrm{UFC} / \mathrm{mL}$.

S.s. and A.a. inocula were separated in 3 tubes each, with a total volume of $2 \mathrm{~mL}$, thus forming 3 groups. All groups were mixed for volume homogenization. The Control group (tube 1) contained $1.8 \mathrm{~mL}$ of inoculum and $0.2 \mathrm{~mL}$ of broth (Brucella broth for S.s. and TSB with $0.5 \%$ of yeast extract for A.a.), but no dye or light was applied. The Dye group (tube 2) contained $1.8 \mathrm{~mL}$ of inoculum and $0.2 \mathrm{~mL}$ of $0.01 \%$ toluidine blue-O (TBO) (weight/volume), which was left for 5 min, but no light was applied; The Dye/Laser group (tube 3) contained $1.8 \mathrm{~mL}$ of inoculum and $0.2 \mathrm{~mL}$ of $0.01 \% \mathrm{TBO}$; illumination with the laser light source was performed, characterizing the PDT protocol. In tube 3, the inoculum was left in contact with TBO for 5 min without shaking (pre-irradiation time) to allow greater absorption of dye by the bacteria. Illumination of the photosensitizer (dye) was done with a AlGaInP (aluminum-gallium-indium-phosphide) diode laser (TwinFlex; (MmOptics ${ }^{\circledR}$, São Carlos, SP, Brazil) with $660 \mathrm{~nm}$ wavelength, $40 \mathrm{~mW}$ output power, $10 \mathrm{~J} / \mathrm{cm}^{2}$ energy density and 3-min irradiation time.

For both bacteria, all groups still at $1.5 \times 10^{8}$ $\mathrm{CFU} / \mathrm{mL}$ concentration were mixed and subjected to serial dilutions in $10 \mathrm{~mL}$ tubes containing either Brucella broth (S.s.) or TSB with $0.5 \%$ yeast extract (A.a.) until reaching dilutions of $10^{-6} \mathrm{CFU} / \mathrm{mL}$ (final concentration of $1.5 \times 10^{2} \mathrm{CFU} / \mathrm{mL}$ ).

Diluted tube mixtures were seeded onto Petri dishes containing $20 \mathrm{~mL}$ of Brucella agar (S.s.) and $20 \mathrm{~mL}$ of TSA containing $0.5 \%$ yeast extract (A.a.) according to the Pourplate method. Dishes containing S.s. were incubated in aerobiosis and those containing A.a. were incubated in microaerophilic conditions at $35^{\circ} \mathrm{C}$ for $48 \mathrm{~h}$. Visual counting of CFUs was done under optical microscopy using pencil marks on dishes. Data were analyzed by one-way ANOVA and Tukey's HSD test at 5\% significance level.

\section{RESULTS}

Counting of all CFU of both bacterial strains remaining in the Control, Dye and Dye/Laser groups was done to determine effectiveness of PDT.

For both bacterial strains, the Control group (no treatment) showed a significantly higher $(\mathrm{p}<0.05)$ bacterial growth $\left(1.5 \times 10^{8} \mathrm{CFU} / \mathrm{mL}\right)$, while the Dye group presented no statistically significant $(\mathrm{p}>0.05)$ bacteria reduction, indicating that the dye alone seems not to reduce bacterial viability. In the Dye/Laser group, however, both bacterial strains were sensitive to the PDT protocol, presenting a significantly less expressive

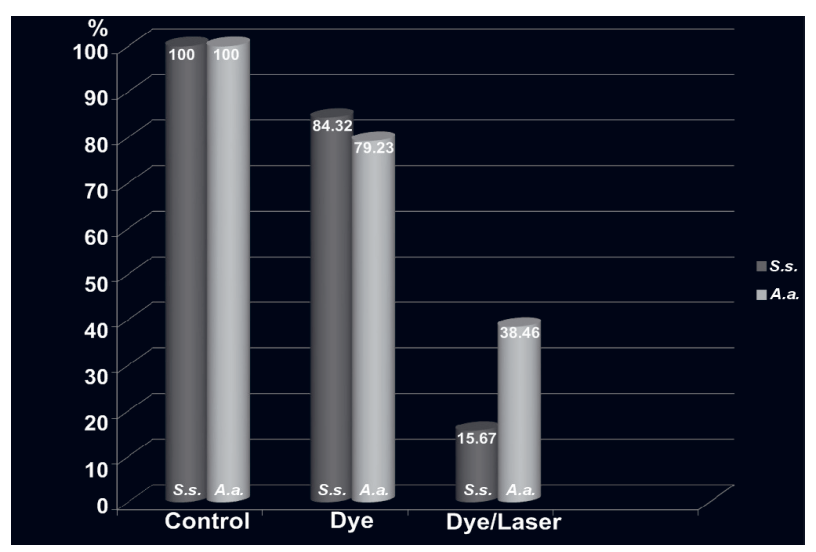

Figure 1. CFU reduction (\%) after treatments. 
bacterial growth. There was a significant reduction in the CFU counts $(p<0.05)$ compared with the initial numbers recorded in both Control and Dye groups.

The results of PDT on S.s. and A.a. in terms of CFU counts (\%) after treatment can be seen in Figure 1.

Statistical analysis for S.s. revealed a nonsignificant reduction (15.68\%) of CFU counts between the Dye and Control groups. However, a significant reduction $(84.33 \%)$ of CFU counts was observed for the Dye/Laser group compared with the Control group (Fig. 2). For A.a., there was a non-significant reduction (20.77\%) of CFU counts in the Dye group compared with the Control group. However, there was an expressive bacterial reduction (61.54\%) when the Dye/Laser group was compared with the Control group (Fig. 3).

\section{DISCUSSION}

The results of this study were confirmative of the in vitro bactericidal efficacy of PDT against the oral pathogens S.s. and A.a..

Correlation between plaque formation and periodontal disease etiology was established with the understanding that plaque maturation is the trigger for the start of inflammatory processes (2), which leads to the destruction of periodontal tissues (9). Traditional scaling and root planning are essential procedures in periodontal therapy (10) and rely on mechanical removal of plaque, calculus, root-bound toxins and contaminated cementum (11). A viable dental plaque covers calculus deposits, which contributes substantially to the pathogenesis of bacteria-induced periodontal disease (12). The main goal of periodontal therapy is to reduce inflammation and allow new epithelial attachment. Biocompatibility of root surface plays a crucial role in the process of periodontal regeneration, in which morphological and chemical alterations may interfere (13).

A disadvantage of mechanical treatment is
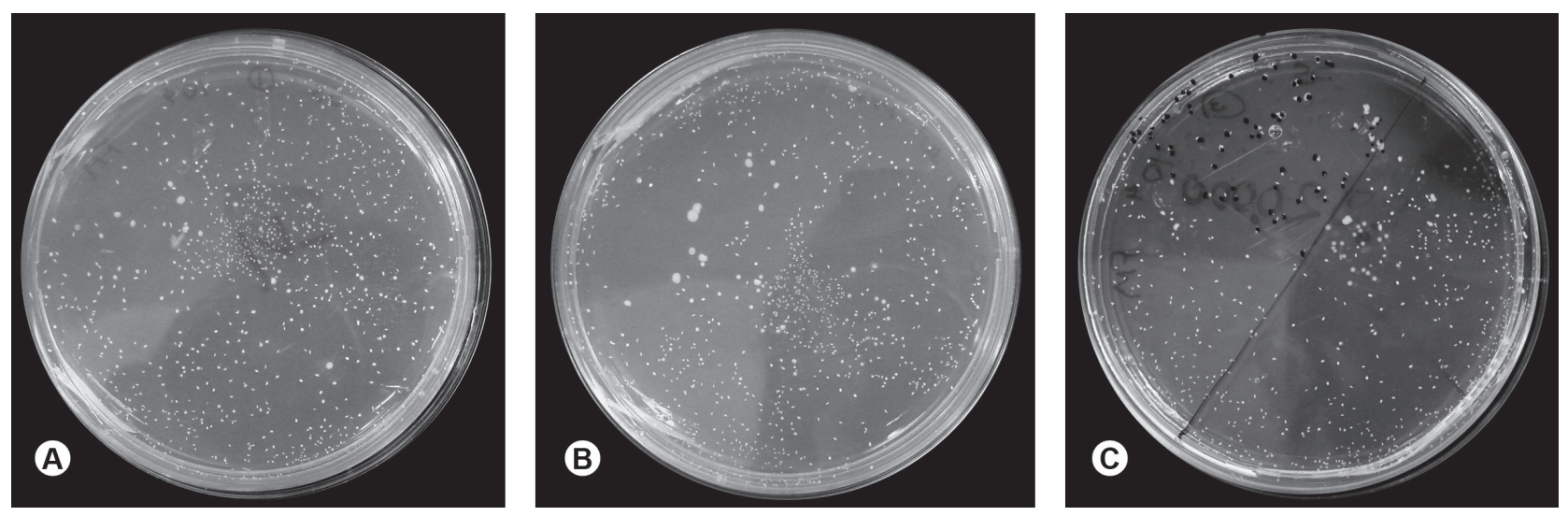

Figure 2. Comparison of Streptococcus sanguinis growth in the Control (A), Dye (B) and Dye/Laser (C) groups.
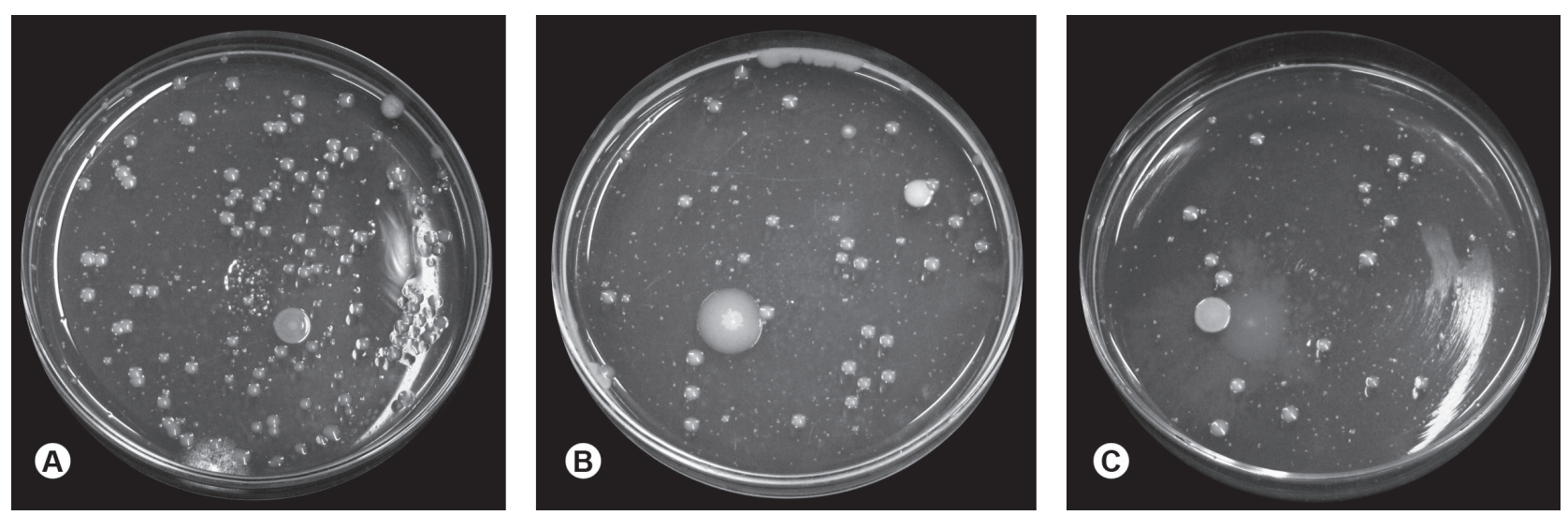

Figure 3. Comparison of Aggregatibacter actinomycetemcomitans growth in the Control (A), Dye (B) and Dye/Laser (C) groups. 
the difficulty of instrument access, visualization of the scaler action (10) and incomplete removal of bacterial deposits and their toxins from the root surface and periodontal pockets. Thus, systemic and local antibiotics are occasionally administered for disinfection, but there are disadvantages, such the difficulty to maintain local therapeutic concentrations sufficient to ensure microbial eradication, and the possibility of affecting normal microflora causing opportunistic infections (5).

PDT has emerged as a therapeutic option for the treatment of infectious diseases (14). It consists in the combination of a non-toxic dye (photosensitizer) with a light source. This therapy involves delivering of low-level visible light of appropriate wavelength to activate the photosensitizer molecule to an excited state, leading the formation of reactive oxygen species, that ultimately kill microorganisms by causing irreversible damage to essential intracellular molecules (15).

The use of PDT as an antimicrobial control method has some characteristics of being a topic therapy, since the dye is applied exclusively into the infected area. Thus, it presents local and specific effects, preventing overdoses and reducing the chances of side effects associated with systemic drug administration (16). It also shows better access to sites unreached by conventional therapy and a selectivity of the photosensitizer for the microbes, avoiding damages to the host's tissues in the infection area (8).

PDTpresents someadvantagesoverconventional antibiotic therapy, such as rapid elimination of target microorganisms (within seconds or minutes, depending on energy density and power used) and absence of maintenance of high concentrations of dye on lesions during hours or days as observed in conventional therapy. Due to production of singlet oxygen and free radicals, which are responsible for mediating bacterial killing, the development of resistance to lethal photosensitization by the target organisms would be a very unlikely event. Another advantage relates to the restriction of antimicrobial effects to the lesion through careful application of the dye and light source, without affecting the adjacent normal microflora. Also, PDT acts eliminating diseasecausative microorganisms and their virulence factors; in conventional therapy, on the other hand, there is only elimination of microorganisms without any effect on virulence factors produced by them. As a consequence, lipopolysaccharides and proteolytic enzymes can continue to exert their adverse effects on the host's healthy tissues, even long after microorganisms had been killed by antibiotic drugs (5).

The first light sources used in PDT were conventional lamps with no-coherent and polychromatic light, and a strong thermal component associated with light emission. They were later replaced by light-emitting diodes and low-level diode lasers. Lasers are far more efficient than conventional lamps as they emit unidirectional, monochromatic and coherent light on time and space. Lasers can be combined with known photosensitizers with resonant absorption bands to the laser wavelength, thus being capable of absorbing greater part of the emitted radiation (17). Diode lasers use a semiconductor solid (e.g.: AlGaInP) to transform electrical energy into light energy. Advantages of diode lasers are their compact size and accessible price (6).

An ideal photosensitizer must be biologically stable, photochemically efficient, selectively retained in the target tissue and should have minimal toxicity to other than the target area (17). The choice for $0.01 \%$ TBO in the present study was due to its compatible wavelength with the light source, providing higher absorption and efficiency (16), and its bactericidal activity under illumination (18). It was verified only a little increase in temperature $\left(0.5-3.9^{\circ} \mathrm{C}\right)$ in the Dye/Laser group, confirming that absorption of laser energy by the dye to inactivate bacteria did not cause overheating. It suggests that dye did not convert laser energy into heat, which could interfere on bacteria viability (16).

Kömerik et al. (19) promoted an in vivo study to assess PDT effectiveness on microbial viability, through $P$. gingivalis inoculation on the upper molar region of rats. TBO at concentrations of $0.01,0.1$ and $1 \mathrm{mg} / \mathrm{mL}$ was used as the photosensitizer. A diode laser emitting at $630 \mathrm{~nm}$ was used as the light source with energy doses of $6,12,24$ and $48 \mathrm{~J}$, corresponding to exposure times of 1, 2, 4 and $8 \mathrm{~min}$, respectively. The histological analysis revealed no alterations in periodontal structures, such as connective tissue ulcerations or inflammation, even at the higher dye concentration or laser dose. Thus, they concluded that PDT with TBO as photosensitizer provided a remarkable decrease of periodontal pathogens without damaging host's tissues. Alveolar bone loss was significantly lower in rats submitted to PDT, being 
an alternative antimicrobial therapy to periodontal disease treatment.

In the present study, the use of PDT promoted a greater bacterial reduction of S.s. numbers compared with A.a. Lesser susceptibility of Gram-negative species is explained by their physiology, as their cell envelope consists of an inner cytoplasmic membrane and an outer membrane that forms a physical and functional barrier between the cell and the environment and is responsible for the maintenance of the bacteria shape (8).

A preliminary study confirmed that the ability of the laser light to kill periodontal pathogens is species-dependent. It appears that $F$. nucleatum and A. actinomycetemcomitans are more resistant to killing than $P$. gingivalis and $P$. intermedia. S. sanguis presented to be the most susceptible strain to PDT(16).

Photokilling of bacterial cells begins when the light with compatible wavelength with the photosensitizer, excites its molecule to the excited singlet state. Then, this molecule emits fluorescence and decreases back to a lower energy, but longer lived state, known as triplet state. Further, the molecule at triplet state reacts through Type I or Type II pathway, both of which require oxygen. Type I pathway involves electron-transfer reactions from the excited photosensitizer at triplet state with surrounding oxygen molecule, hence, providing cytotoxic species, such as peroxides $\left(\mathrm{ROO}^{-}\right)$, superoxide $\left(\mathrm{O}_{2}^{-}\right)$, hydroxyl $\left(\mathrm{OH}^{-}\right)$, promoting the membrane or macromolecules destruction. Type II pathway occurs depending on the location of the photosensitizer in the cell, and the triplet state photosensitizer transfers its electrons to oxygen molecules, changing from triplet ground state $\left({ }^{3} \mathrm{O}_{2}\right)$ to the singlet excited state $\left({ }^{1} \mathrm{O}_{2}\right)$, which may oxidize several biological molecules, such as proteins, nucleic acids and lipids, and lead to cytotoxicity (20).

According to Chan and Lai (16), the exposure of periodontopathogenic bacteria to $665 \mathrm{~nm}$ diode laser with power output of $100 \mathrm{~mW}$ in presence of $0.01 \% \mathrm{TBO}$ as the photosensitizer resulted in a dose-dependent decrease of viable bacterial strains. Maintaining a constant power with an exposure time of $30 \mathrm{~s}$ and energy density of $10.6 \mathrm{~J} / \mathrm{cm}^{2}$ resulted in a bacterial decrease between $71-88 \%$. However, increasing the exposure to $60 \mathrm{~s}$ and energy density to $21.2 \mathrm{~J} / \mathrm{cm}^{2}$, there was a $99-100 \%$ reduction of $P$. intermedia, P. gingivalis and S.s. sanguis, while A.a. and $F$. nucleatum numbers decrease by 95 and $96 \%$, respectively.

The results of the present study are confirmative of the efficiency of PDT, using a TBO as the photosensitizer and a low-level diode laser as the light source on oral pathogenic bacteria S.s. and A.a. This therapy appears as a viable option, as it is easy to perform and has low cost; is efficient in restricted infections without systemic effects without risks of bacterial resistance, as with other therapies. Therefore, under the tested conditions, PDT seemed to be suitable as an adjunct to conventional periodontal therapy, contributing to the establishment of biological compatibility of diseased root surfaces, for subsequent periodontal tissue regeneration. Further in vivo studies must be conducted due to the broad range of variables present in this therapy, aiming its clinical applicability.

\section{RESUMO}

Novos tratamentos são propostos para evitar a progressão da periodontite, sendo a terapia fotodinâmica (PDT) uma notória promessa. Sua aplicação associa o Azul de orto-toluidina a $0,01 \%$ (TBO) e uma fonte luminosa a laser de diodo (TwinFlex, Mmoptics), liberando assim, toxinas às bactérias. $\mathrm{O}$ objetivo do estudo é avaliar in vitro a eficiência da PDT sobre Aggregatibacter actinomycetemcomitans (A.a.) e Streptococcus sanguinis (S.s.). Preparou-se suspensões distintas de $2 \mathrm{~mL}$ contendo A.a. e S.s. na concentração de 1,5x108 UFC/mL, e divisão de cada suspensão em 3 grupos: Controle (sem tratamento); Corante (suspensão e TBO por 5min) e Corante/Laser (suspensão, TBO por 5 min e laser por $3 \mathrm{~min}$ ). Promoveu-se a diluição, a semeadura em $20 \mathrm{~mL}$ de TSA (A.a.) e de Ágar Brucella (S.s.), em placas de Petri (Método Pourplate), e a incubação da A.a. em microaerofilia e da S.s. em aerobiose, por $48 \mathrm{~h}$ a $35^{\circ} \mathrm{C}$, para posterior contagem visual das UFC. Os grupos Controle mostraram ótimo crescimento bacteriano $\left(1,5 \times 10^{8} \mathrm{UFC} / \mathrm{mL}\right)$. Os grupos Corante não apresentaram redução significativa para ambas bactérias. Os grupos Laser apresentaram redução em relação ao controle, $61,53 \%$ para A.a. e 84,32\% para S.s. A análise estatística (ANOVA, $\mathrm{p}<0,05)$ corrobou que a PDT é eficaz na redução destas bactérias in vitro.

\section{ACKNOWLEDGEMENTS}

The authors would like to thank Mmoptics (São Carlos, SP, Brazil) for providing the diode laser TwinFlex, and the assistance of Prof. Dr. José Luiz Guimarães de Figueiredo in the development of the study.

\section{REFERENCES}

1. Paik S, Senty L, Das S, Noe JC, Munro CL, Kitten T. Identification of virulence determinants for endocarditis in Streptococcus sanguinis by signature-tagged mutagenesis. Infect Immun 2005;73:6064-6074.

2. Kolenbrander PE, Palmer Jr RJ, Rickard AH, Jakubovics NS, 
Chalmers NI, Diaz PI. Bacterial interactions and successions during plaque development. Periodontol 2000 2006;42:47-79.

3. Schacher B, Baron F, Roßberg M, Wohlfeil M, Arndt R, Eickholz P. Aggregatibacter actinomycetemcomitans as indicator for aggressive periodontitis by two analyzing strategies. J Clin Periodontol 2007;34:566-573.

4. Rêgo ROCC, Spolidorio DMP, Salvador SLS, Cirelli JA. Transmission of Aggregatibacter actinomycetemcomitans between Brazilian women with severe chronic periodontitis and their children. Braz Dent J 2007;18:220-224.

5. Wilson M. Lethal photosensitisation of oral bacteria and its potential application in the photodynamic therapy of oral infections. Photochem Photobiol Sci 2004;3:412-418.

6. Aoki A, Sasaki KM, Watanabe H, Ishikawa I. Lasers in nonsurgical periodontal therapy. Periodontol 2000 2006;36:59-97.

7. Mettraux G, Hüsler J. The antibacterial photodynamic therapy after scaling and root planing in the transgingival application mode - A proof of principle controlled clinical study. Schweiz Monatsschr Zahnmed 2011;121:53-60.

8. Hamblin MR, Hasan T. Photodynamic therapy: a new antimicrobial approach to infectious disease? Photochem Photobiol Sci 2004;3:436-450.

9. Rapp GE, Pineda-Trujillo N, McQuillin A, Tonetti M. Genetic power of a Brazilian three-generation family with generalized aggressive periodontitis. II. Braz Dent J 2011; 22:68-73.

10. Soares PBF, Menezes HHM, Naves MM, Taga EM, Magalhães D. Effect of absorbent tetracycline-loaded membrane used in the reduction of periodontal pockets: an in vivo study. Braz Dent $\mathrm{J}$ 2009;20:414-418.

11. Grisi DC, Salvador SLS, Marcantonio RAC. Efficacy of Carisolv as an adjunctive therapy to scaling and root planing on subgingival calculus removal. Braz Dent J 2006;17:213-218.
12. Soares PBF, Magalhães D, Fernandes Neto AJ, Castro CG, Santos Filho PCF, Soares CJ. Effect of periodontal therapies on indirect restoration: a scanning electron microscopic analysis. Braz Dent J 2010;21:130-136.

13. Gaspirc B, Skaleric U. Lasers in Periodontics. J Oral Laser Applications 2003;3:135-140.

14. Miyabe M, Junqueira JC, Da Costa ACBP, Jorge AOC, Ribeiro MS, Feist IS. Effect of photodynamic therapy on clinical isolates of Staphylococcus spp. Braz Oral Res 2011;25:230-234.

15. Moore CM, Pendse D, Emberton M. Photodynamic therapy for prostate cancer - a review of current status and future promise. Nat Rev Urology 2009;6:18-30.

16. Chan Y, Lai CH. Bactericidal effects of different laser wavelengths on periodontopathic germs in photodynamic therapy. Lasers Med Sci 2003; 18:51-55

17. Ackroyd R, Kelty C, Brown N, Reed M. The history of photodetection and photodynamic therapy. Photochem Photobiol 2001;74:656-669.

18. Usacheva MN, Teichert MC, Biel MA. Comparison of the methylene blue and toluidine blue photobactericidal efficacy against gram-positive and gram-negative microorganisms. Lasers Surg Med 2001;29:165-173

19. Komerik N, Nakanishi H, MacRobert AJ, Henderson B, Speight $\mathrm{P}$, Wilson M. In vivo killing of Porphyromonas gingivalis by toluidine blue-mediated photosensitization in an animal model. Antimicrob Agents Chemother 2003;47:932-940.

20. Nayak CS. Photodynamic therapy in dermatology. Indian J Dermatol Venereol Leprol 2005;71:155-160.

Received September 17, 2010 Accepted April 24, 2011 